\title{
Reproductive Performance and Milk Production of Assaf Sheep in an Intensive Management System
}

\author{
G. E. Pollott ${ }^{1}$ and E. Gootwine ${ }^{2}$ \\ ${ }^{1}$ Department of Agricultural Sciences, \\ Imperial College London, Wye campus, \\ Ashford, Kent, TN25 5AH, UK \\ ${ }^{2}$ Department of Genetics, Institute of Animal Science, \\ Agricultural Research Organisation, The Volcani Center, \\ PO Box 6, Bet Dagan, 50250, Israel
}

\begin{abstract}
The Assaf breed of dairy sheep, a stabilized cross of the Awassi and East Friesian breeds, has replaced the Awassi as the breed of choice in its country of origin, Israel, and has spread to other Mediterranean countries. In Israel the Assaf breed is managed under an intensive production system involving weaning lambs at birth, rearing them artificially, and milking ewes after parturition. There are several breeding periods in the year when ewes are mated following hormonally synchronized estrus. Records of 18,976 lactations from 5 farms were analyzed to investigate factors that influenced Assaf milk and reproductive performance. Lactation curves were fitted to each lactation, and a range of parameters and calculated values were analyzed. Daily milk yield records also were analyzed to describe a typical Assaf lactation and compared with those of the Awassi breed. Factors affecting age at first lambing also were studied. An average Assaf ewe kept under this intensive management regimen was found to produce $334 \mathrm{~L}$ of milk during a 173-d lactation. Mean litter size was 1.57 lambs/ewe lambing, and lambing interval was $272 \mathrm{~d}$. Milk production was affected by litter size, with twin- and triplet-bearing ewes producing approximately $20 \mathrm{~L}$ more milk per lactation than single-bearing ewes. Day length was the major environmental variable influencing milk yield. The difference between midsummer and midwinter day lengths accounted for a difference in daily milk yield of $0.44 \mathrm{~L}$ in favor of summer. Ewe lambs that were mated for the first time at later ages produced more lambs and more milk due to greater early lactation characteristics. Milk production was found to be negatively associated with subsequent reproductive performance. Comparing these results with those from an earlier study in the Awassi breed, the
\end{abstract}

Received March 18, 2004.

Accepted June 28, 2004.

Corresponding author: Elisha Gootwine; e-mail: gootwine@ agri.gov.il.
Assaf was found to produce less milk during a shorter lactation than the Awassi, but its greater litter size made it a more profitable breed.

(Key words: Assaf, dairy sheep, lamb production, seasonality)

Abbreviation key: CTMY = calculated total milk yield, $\mathbf{M C}=$ month after lambing when conception occurred, $\mathbf{M S}=$ maximum secretion potential.

\section{INTRODUCTION}

The Assaf dairy sheep breed, originating from a cross consisting of the Awassi and East Friesian breeds, was developed in Israel during the 1950s and 1960s. The Assaf breed not only has replaced the improved Awassi as the main dairy breed in the country (Epstein, 1985; Gootwine and Goot, 1996), but also has been bred successfully in other countries (Ugarte et al., 2000). Currently, Assaf ewes are maintained in Israel under an intensive management system, where ewes are milked from lambing, and lambs are transferred at birth to artificial rearing units. In addition, reproductive management of Assaf sheep includes hormonal estrus synchronization and several mating periods during the year. Such a management system is targeted to exploit the full biological potential of the Assaf for both lamb and milk production. To achieve this goal, knowledge of the environmental constraints that affect both production and reproductive traits is of interest.

Factors affecting milk and lamb production of the improved Awassi breed maintained in similar intensive conditions have been described by Gootwine and Pollott (2000). The latter study highlighted the significant effect of seasonality on milk production and estimated the effect of environmental factors such as heat load, day length, and change in day length on milk production. In addition, high milk production was found to have an adverse effect on reproductive performance and conception during the milking period following a significant short-term variation in milk production. 
The positive effect of long days during lactation on milk production was recognized in dairy cattle (Dahl et al., 2000) and in sheep (Gootwine and Pollott, 2000). Short day length during the prepartum period may have a positive effect on milk production during subsequent lactation in dairy cattle (Aharoni et al., 2000; Miller et al., 2000). To what extent such a prepartum photoperiod effect alters milk production in dairy sheep has not been investigated.

Production of Assaf sheep, with ewes and lambs managed together until weaning, has been reported (Goot, 1974; Eyal et al., 1978; Epstein, 1985). Some limited information on current performance of the Assaf under intensive management was presented by Gootwine and Pollott (2002).

The aim of the present study was to investigate the performance of the Assaf and the factors affecting its lamb and milk production. The fact that Assaf ewes are milked immediately after lambing makes it possible to analyze the complete lactation curve of the Assaf using a biological model (Pollott, 2000) in which functions that describe udder secretory cell proliferation and death are included.

\section{MATERIALS AND METHODS}

\section{Management}

The flocks providing data for this study were kept indoors all year round, and the ewes were fed concentrates, silage, and hay to meet their nutritional requirements according to their level of production. Young ewes were first exposed to the ram at approximately 9 mo of age. Reproductive management included several breeding periods per year in which ewes were hand mated or inseminated following hormonally synchronized estrus, performed on dry ewes or lactating ewes at approximately $90 \mathrm{~d}$ after lambing. Lambs were transferred at birth to artificial rearing units, and ewes were milked twice daily from the day of lambing until their milk yield dropped to approximately $0.5 \mathrm{~L} / \mathrm{d}$, or when they were dried off before lambing. After weaning, ewe and ram lambs were fed concentrates, hay, and silage to ensure optimal growth until puberty.

\section{Records}

Information used in this study was derived from the Assaf flocks of Kibbutz Dalia, Kibbutz Gazit, and Kibbutz Nachshon, Moshav Nordia, and from the flock of Asher Meisels at Moshav Orot. These flocks were located in north-central Israel. The information included records of 9660 ewes that lambed and were milked between January 1993 and June 2002. In these flocks, performance records were collected, stored, and vali- dated using on-farm Ewe and Me software (Gootwine et al., 1994).

\section{Parameters Calculated}

Daily milk yields, collected monthly, and the date of the test-day were recorded for up to 9 occasions during lactation, starting within 1 mo of lambing, for all ewes in the flocks. A range of performance data and other information were recorded on all ewes, including date of birth, date of lambing, lactation number of the ewe, and litter size at lambing. These data were used to calculate further performance information. Lambing interval was calculated as the number of days between successive lambings of the same ewe. Lactation length was the number of days between lambing and the last monthly milk record. The date of conception during the lactation was estimated by subtracting $146 \mathrm{~d}$, the average gestation length of Assaf ewes, from the date of the next lambing. The day in lactation when conception occurred was calculated by subtracting the lambing date from the date of conception and dividing by 30 to give the month of lactation when conception occurred (MC). Milk yield was recorded on approximately the 15th day of each month for all lactating ewes in the flock, and daily records were used to estimate total lactation milk yield using the formula:

$$
T M Y=\left(T_{1}-T_{0}\right) M_{1}+\sum_{2}^{r}\left(T_{r}-T_{r-1}\right)\left(M_{r}+M_{r-1}\right) / 2
$$

where $T_{0}=$ date of lambing, $T_{r}=$ date of the various monthly milk recordings, and $M_{r}=$ daily milk yield at monthly recording $r$ (Pollott and Gootwine, 2000).

\section{Individual Lactation Curves}

Daily milk records were selected from all lactations having at least 4 test-day records. The 3-parameter reduced multiplicative model (model 1) described by Pollott (2000) was fitted to each lactation using the NLIN procedure of SAS (1989), which is an iterative, nonlinear, curve-fitting procedure. The best fit curve was obtained for each lactation when there was $<10^{-6}$ difference between the error sums of squares in successive iterations.

$$
M=\left[M S /\left(1+a e^{-G R t}\right)\right]\left(2-e^{D R t}\right),
$$

where $M S$ = maximum secretion potential of the lactation (Pollott, 2000), GR = relative proliferation rate of secretory cell numbers during early lactation, $D R=$ relative decline in cell numbers as lactation progressed, $t=$ day of lactation -90 , and $a=(1-0.9999999) /$ 
Table 1. Mean and standard deviation of litter size and 11 lactation parameters of Assaf sheep analyzed in this study and comparable data from Awassi ewes.

\begin{tabular}{|c|c|c|c|c|}
\hline \multirow[b]{2}{*}{ Trait } & \multicolumn{2}{|c|}{ Assaf data $(\mathrm{n}=18,976)$} & \multicolumn{2}{|c|}{ 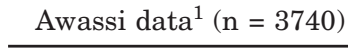 } \\
\hline & Mean & SD & Mean & SD \\
\hline Litter size & 1.57 & 0.60 & 1.28 & 0.50 \\
\hline Total milk yield, L & 334 & 133 & 506 & 161 \\
\hline Lactation length, $d$ & 173 & 42 & 214 & 49 \\
\hline Lambing interval, d & 272 & 66 & 330 & 90 \\
\hline Maximum secretion potential, L/d & 2.89 & 0.99 & 3.90 & 1.15 \\
\hline Relative growth rate in cell numbers & 0.027 & 0.038 & 0.067 & 0.055 \\
\hline Relative death rate in cell numbers & 0.0151 & 0.006 & 0.0204 & 0.007 \\
\hline Day of peak yield, d & 24 & 12 & 45 & 20 \\
\hline Peak yield, L/d & 2.61 & 0.87 & 3.44 & 0.99 \\
\hline Increase in milk yield midway & & & & \\
\hline $\begin{array}{l}\text { between lactation start and peak, g/d } \\
\text { Decrease in milk yield halfway }\end{array}$ & 71.7 & 61.2 & 62.0 & 31.9 \\
\hline between lactation peak and end, g/d & 11.3 & 6.4 & 16.5 & 9.1 \\
\hline Calculated total milk yield, L & 317 & 126 & 482 & 157 \\
\hline
\end{tabular}

${ }^{1}$ From Gootwine and Pollott (2000).

0.9999999. Both $t$ and $a$ were used in this form to reduce by 1 the number of parameters calculated (Pollott and Gootwine, 2001). This approach was based on the assumption that the secretion rate of milk per cell was fixed throughout lactation (Pollott, 2000).

\section{Calculated Characteristics of the Curve}

Peak yield, day of peak yield, calculated total milk yield (CTMY), and persistency of lactation (i.e., rate of decline in milk yield midway between the peak and the end of lactation) were calculated for each lactation (Pollott, 2000). Rate of increase in milk production midway between the start and peak of lactation also was calculated.

\section{Analyses of Lactation Traits}

Individual lactation records were analyzed to investigate the factors influencing milk production in Assaf ewes. Model 2 was fitted to the 12 lactation traits shown in Table 1, using the GLM procedure of SAS (1989):

$$
\begin{gathered}
Y_{i j k l m n o}=\mu+F_{i}+E_{j}\left(F_{i}\right)+M N_{k}+Y R_{l} \\
+L N O_{m}+L S_{n}+b_{1} M C+b_{2} M C^{2}+e_{i j k l m n o}
\end{gathered}
$$

where $\mu=$ overall least square mean, $F_{i}=$ farm $i$ ( $i=1$ to 5 ), and $E_{j}\left(F_{i}\right)=$ ewe $j$ on farm $i$ lambing in month $k$ $(M N ; k=1$ to 12$)$ of year $l(Y R ; l=1993$ to 2002$)$. The ewe was in lactation $m$ ( $L N O ; m=1$ to 10$)$ and gave birth to $n$ lambs at the start of lactation $(L S ; n=1$ to 4). Gootwine and Pollott (2000) reported that the effect of the month in lactation when conception occurred $(M C$; as a fixed effect) on lactation traits was curvilinear. Therefore, in model $2, M C^{2}$ was included with $M C$, and both were included as covariates to fit a curvilinear relationship, with $b_{2}$ and $b_{1}$ as their respective regression coefficients. The term $e_{i j k l m n o}$ represented the normally distributed random error term. All first-order interactions were fitted, as was the second-order interaction between flock, year, and month. Traits and interactions were dropped from successive iterations of the model if they were not significant $(P>0.05)$, starting with the least significant. The final model comprised all terms that were found to be significant plus any main effects that were not significant, provided that one of the interactions in which they were involved was significant. For the lambing interval analysis, $M C$ was omitted from the model because the 2 traits were highly correlated. Least square means were computed for each of the significant fixed effects. Differences between levels of any set of fixed effects were tested using a modified Fisher's least-significant difference test (SAS, 1989).

The repeatability of each trait and its standard error were estimated using the same final models as described above using the ASREML software (Gilmour et al., 2002). Ewe was treated as a random effect and its variance estimated. Repeatability was calculated as the ratio between the ewe and phenotypic variance components, with the latter calculated as the sum of the ewe and residual variance components.

Correlations between all 12 traits were computed by fitting model 2 to all traits simultaneously using the MANOVA option of the GLM procedure in SAS (1989). The MANOVA option computed the sums of cross-products for all combinations of the traits from which all correlations were calculated.

\section{Age at First Lambing}

Further analyses were undertaken on the lactation data to investigate the effect of age at first lambing on 
performance early in the ewe's life. Age at first lambing was calculated for each ewe with a recorded first lambing in the data set. Model 2 was fitted to 4597 first lactation records, omitting lactation number and including age at first lambing as a covariate using the same methods as described above. To determine any carryover effects of age at first lambing on subsequent lambings, the same model was fitted to data from 4130 second lactations and then again to 3647 third lactations.

\section{Analyses of Daily Milk Yield}

Several factors were analyzed to determine their influence on test-day milk yields. Model 3 was fitted to daily milk yield using the GLM procedure of SAS (1989):

$$
\begin{gathered}
M_{\text {ijklmnopqrs }}=F_{i}+E_{j}\left(F_{i}\right)+M N_{k}+Y R_{l} \\
+L N O_{m}+L S_{n}+M C_{o}+W_{p}+W C_{q}+e_{i j k l m n o p q r s}
\end{gathered}
$$

Some terms in model 3 were the same as those in model 2 , plus the addition of week $p$ of lactation and week $q$ of the record in relation to conception, except $\mathrm{MN}$ and $Y R$ were the month and year of the test-day record in these analyses. The term $M C$ was fitted as a fixed effect in model 3. All 2-way interactions were tested in the model in addition to the 3 -way interaction of farm, year, and month of record. The downwards-stepwise method for fitting model 3 was used as described above. All ANOVA results used Type III sums of squares, and least square means were computed for each of the fixed effects. Fitting week of lactation as a fixed effect resulted in least square means describing a "typical" Assaf lactation curve.

\section{Environmental Effects}

Heat load and photoperiodic effects on sheep milk yield have been described by Gootwine and Pollott (2000). To investigate the heat load and the photoperiod effects on Assaf milk production, the $M N$ component of model 3 was replaced by $H L+D L+D C+D L P+D C P$ as covariates. These terms represent the heat load ( $H L$ measured in index units), the day length ( $D L$ in h), and daily changes in day length $(D C$ in $\mathrm{min} / \mathrm{d}$ ) on the day of recording. Day length during pregnancy $(D L P)$ and day length change during pregnancy $(D C P)$ were the same factors as $D L$ and $D C$ but measured midway through the month prior to lambing. Unfortunately, maximum day and minimum night temperature values provided by the Israeli Meteorological Services for the 5 farm locations were of no help in calculating actual heat load values because ventilation and cooling devices were installed in the sheep sheds. To include the heat

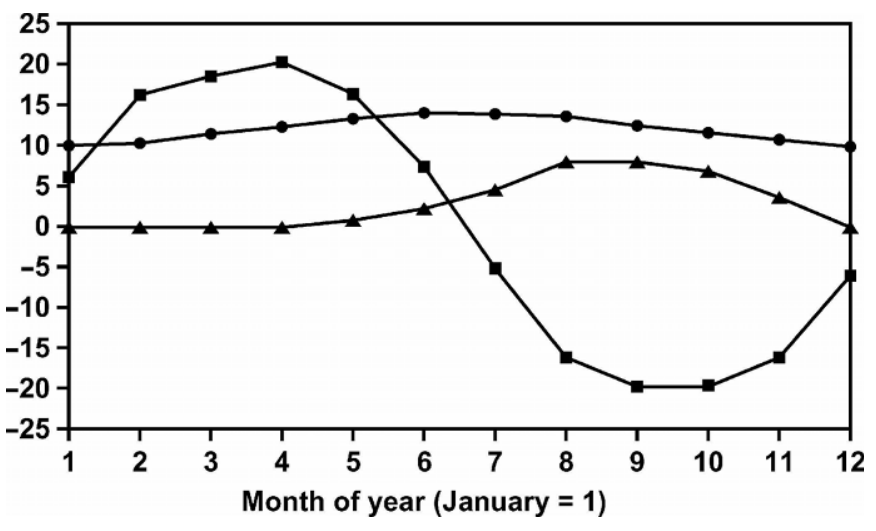

Figure 1. Distribution of day length $(\bullet, \mathrm{h})$, change in day length $(\boldsymbol{\square}, \mathrm{min} / \mathrm{d})$ and heat load $\left(\boldsymbol{\Delta},{ }^{\circ} \mathrm{C} / 10\right)$ values throughout the year.

load effect in the analysis, however, values used in previous work (Gootwine and Pollott, 2000) were considered. These values described conditions in the Eden Farm $\left(32^{\circ} 30^{\prime} \mathrm{N}, 35^{\circ} 30^{\prime} \mathrm{E}\right)$, where climatic conditions were usually more severe during summer than at the 5 farms in this study. Thus, values for $H L / 2$ were included in the present study. Figure 1 shows how heat load, day length, and day length change varied throughout the year. Mean heat load was 28.1 index units; mean day length was $12.0 \mathrm{~h}$, and mean day length change was 0 min. Day length and day length change during pregnancy varied with time and were the same as shown for day length and day length change, but at the time of year corresponding to the month before lambing rather than the time of test-day record. Model 3 was rerun to include all 5 environmental variables, and their interactions with the farm effect, in the model.

\section{RESULTS}

Complete records for the traits and effects of interest were selected from the 5 flocks. This resulted in records from 27,052 lambings and lactations from 13,538 ewes. Lactation curves were fitted to lactation records containing at least 4 test-day records. This reduced the number of lactations available to 18,976 (from 8023 ewes), which were distributed over the 5 farms consisting of $2117,3368,2741,5167$, and 5583 records, respectively.

The means and standard deviations for the $12 \mathrm{com}$ plete lactation traits analyzed in this study are summarized in Table 1 along with comparable data from the other dairy sheep breed in Israel managed under similar intensive conditions, the Improved Awassi (Gootwine and Pollott, 2000). Assaf sheep had an average milk yield of $334 \mathrm{~L}$ during a 173-d lactation. Average litter size was 1.57 lambs per ewe, with an average 
Table 2. ANOVA summary of 12 traits from 18,976 Assaf ewe lactations by 8047 ewes.

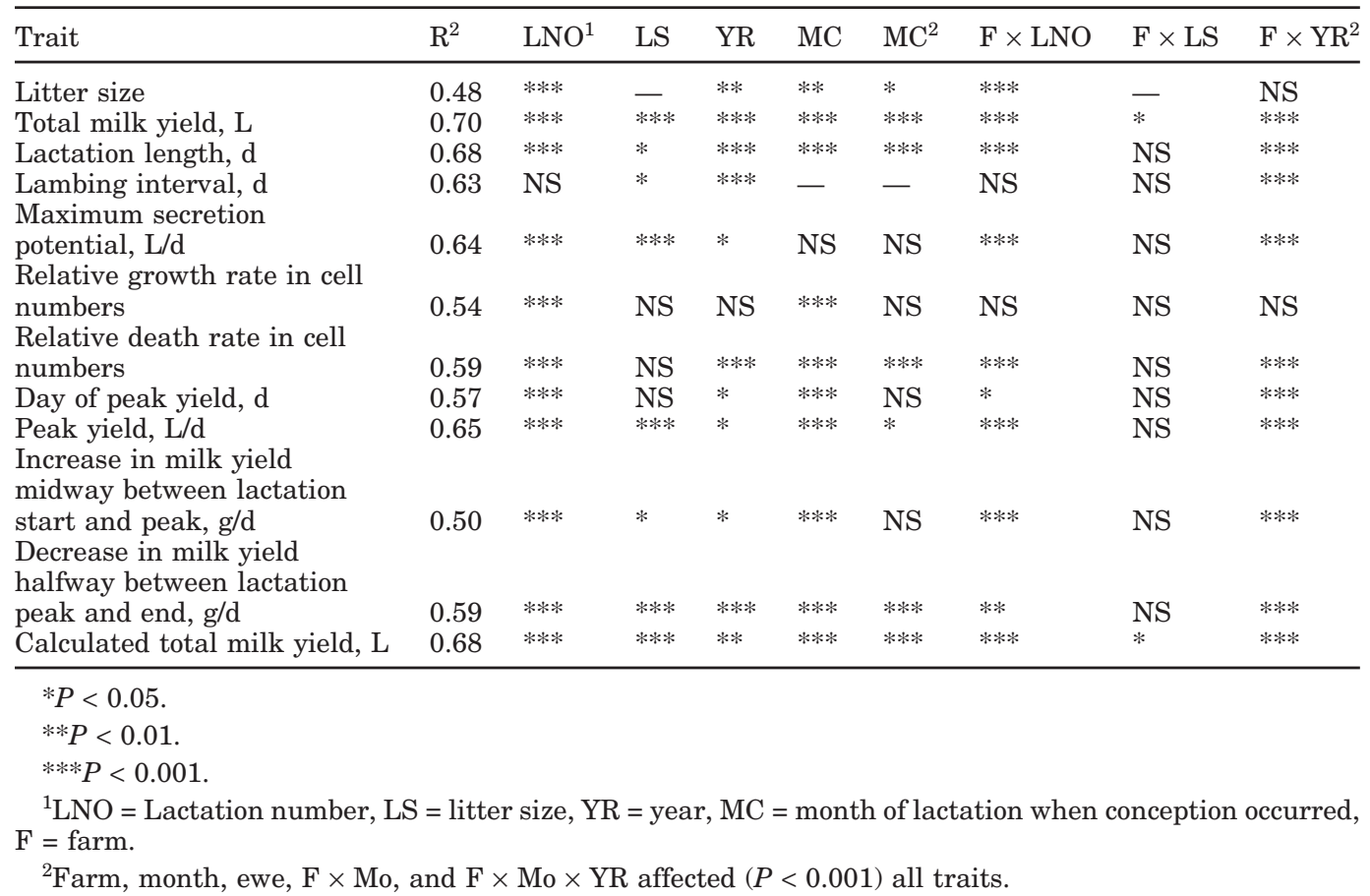

lambing interval of $272 \mathrm{~d}$, resulting in 1.34 lambings/ ewe per year. The maximum secretion potential of the ewes was $2.89 \mathrm{~L} / \mathrm{d}$, which resulted in a peak yield of $2.61 \mathrm{~L} / \mathrm{d}$ at d 24 of lactation. Milk production increased by $71 \mathrm{~g} / \mathrm{d}$ midway between the start and peak of lactation, and persistency was $11.3 \mathrm{~g} / \mathrm{d}$ midway between the peak and end of lactation. Total milk yield calculated from lactation curve parameters averaged $317 \mathrm{~L}$.

Results of analyzing 12 Assaf production traits using model 1 are summarized in Table 2 . The final models fitted the data with $\mathrm{R}^{2}$ values ranging from 0.48 (litter size) to 0.70 (total milk yield), indicating that the models accounted for a large proportion of the variance of the various traits. Farm, ewe, month of lambing, and the interactions between farm and month, and farm with month and year, affected $(P<0.001)$ all traits. Lactation number affected $(P<0.001)$ all traits, except lambing interval, whereas year of lambing affected $(P$ $<0.05$ ) all traits, except relative growth rate of mammary cell numbers during early lactation. Litter size at the start of lactation influenced milk yield and most traits associated with early lactation $(P<0.05)$. The linear effect of month of lactation when conception occurred was associated with all traits $(P<0.01)$, except the maximum secretion potential of the ewe, whereas the nonlinear month of conception $\left(M C^{2}\right)$ term also influenced a number of traits $(P<0.05)$.

Least square means for total milk yield (model 2) was greatest for lactations starting in February (352 L) and was least for those starting in August (298 L; Figure 2).
Unlike sheep production systems with only 1 main lambing season during spring, lambings in the Assaf flocks occurred throughout all months of the year, peaking in March, June, October, and December. A seasonal effect was noted for litter size in which least square means peaked in February and September (Figure 2), the months of the year at the beginning of the 2 main lambing periods.

\section{Correlation Between Traits}

A number of the lactation traits had phenotypic correlations greater than 0.3 (Table 3). Total milk yield was

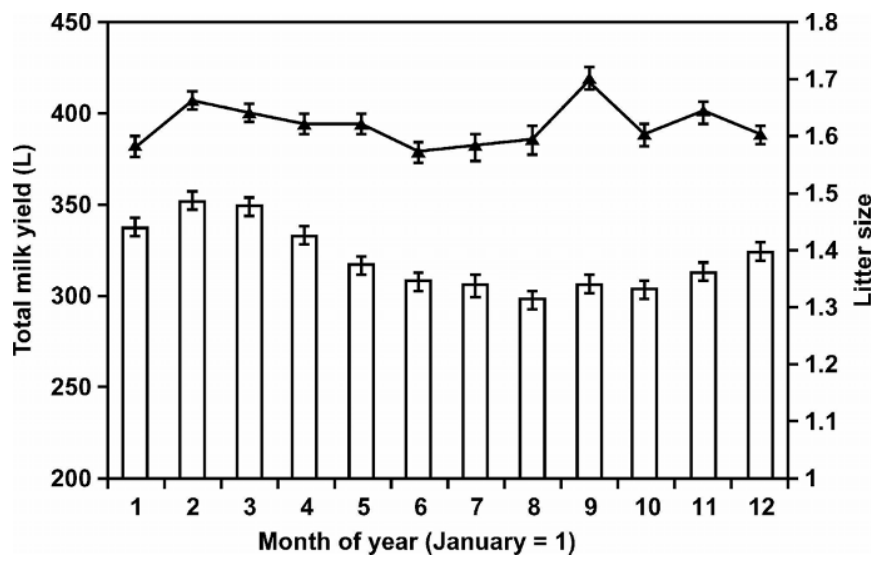

Figure 2. Least square means $( \pm \mathrm{SE})$ for total milk yield (bars) and litter size $(\boldsymbol{\Lambda})$ of lactations starting during different months of the year. 
Table 3. Phenotypic correlations between the 11 lactation traits.

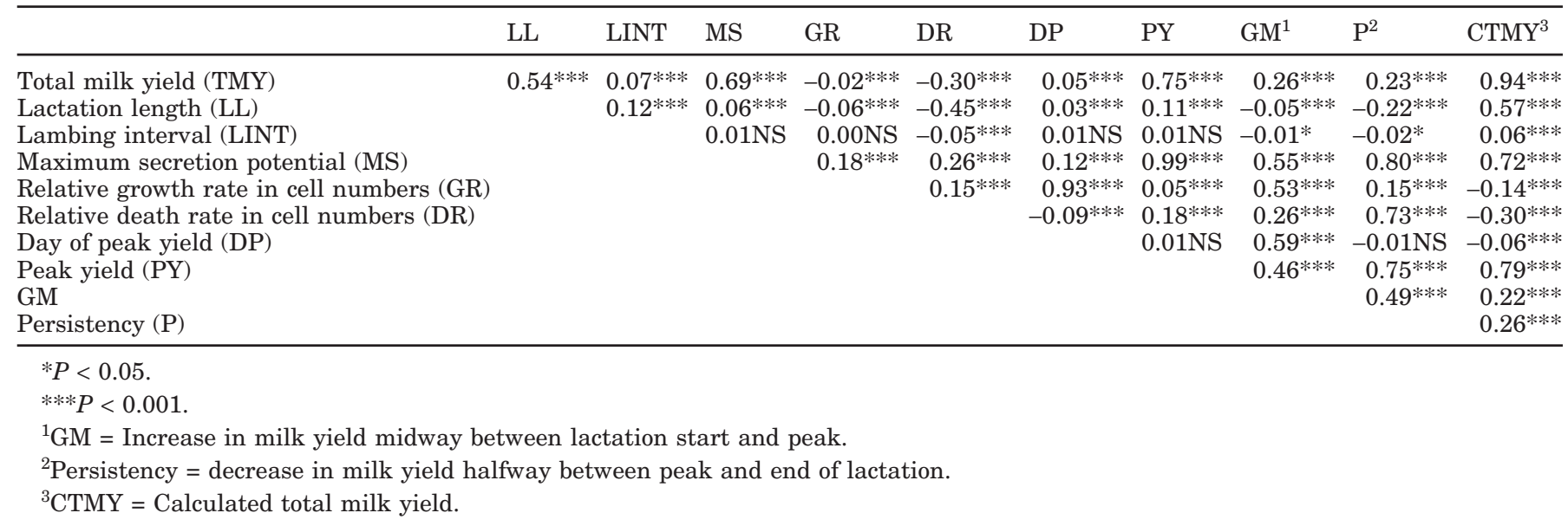

highly correlated with CTMY (0.94), peak yield (0.75), MS (0.69), and lactation length (0.54). The correlation with CTMY is to be expected, but the other 3 demonstrated the importance of lactation length and the peak of the lactation curve as factors influencing milk production throughout the lactation. Table 3 also shows the negative correlation between total milk yield and death rate of cell numbers, emphasizing the relationship between cell numbers and lactation length $(-0.45)$.

Peak yield (and MS) also was highly related to the increase in milk yield midway between the start and peak of lactation (0.46) and persistency (0.75); the greater the peak of lactation, the greater the increase of milk production per day before the peak and the greater the decline after peak.

\section{Repeatability}

Repeatabilities, a term that combines the heritability of the trait and permanent environmental effect of the ewe, of milk yield (total milk yield and CTMY), peak yield, and maximum secretion potential were all approximately $0.3 \pm 0.009$. Very low repeatabilities were found for litter size, lactation length, lambing interval, relative cell growth rate, day of peak yield, and rate of milk increase during early lactation $(<0.09 \pm 0.008)$. Persistency and the relative death rate in cell numbers had repeatabilities of $0.14 \pm 0.008$ and $0.11 \pm 0.009$, respectively.

\section{Litter Size and Milk Production}

Interestingly, litter size influenced a number of lactation traits. These effects are related to the prepartum effect of the number of fetuses carried by the dam because the Assaf ewes in this study did not nurse their lambs after birth. Ewes bearing twins or triplets had a greater $(P<0.05)$ milk yield, by approximately $6 \%$, than single bearing ewes (Table 4). This significant increase in milk production in ewes that carried twins and triplets was followed by an increase of approximately $1 \%$ in lactation length and lambing intervals, and was due mainly to an increase in early lactation parameters such as MS, peak yield, and the increase in milk yield midway between the start and peak of lactation.

\section{Effect of Lambing-Lactation Number on Ewe Performance}

Average litter size of ewes varied with lactation number (Figure 3); it rose from 1.41 lambs/lambing at the first lactation to 1.71 at the fifth lactation, and then declined thereafter. Ewes in their first lactation had the smallest total milk yield, whereas during the second lactation, they had their greatest lifetime milk yield. Milk yield then declined as the ewes aged (Figure 3). Declining milk yield was partly due to decreasing lactation lengths as the ewes aged (Figure 3) but was due also to decreasing maximum secretion potential of the ewe, which followed a similar pattern to total milk yield (Figure 3). The relative growth rate in cell numbers was greatest during first lactation (Figure 3 ) and then was least and constant throughout the remainder of life. The relative death rate of cell numbers, however, increased throughout life. The increase in milk yield midway between the start and peak of lactation (not shown) reflects the combination of relative growth rate in cell numbers and maximum secretion potential. From $68 \mathrm{~g} / \mathrm{d}$ in the first lactation, the amount increased to approximately $74 \mathrm{~g} / \mathrm{d}$ during the third lactation, and then declined as the ewes became older. Persistency of lactation was elevated during the first lactation, with ewes only losing approximately $8 \mathrm{~g} / \mathrm{d}$ in milk yield. In 
Table 4. Effect of litter size on 8 lactation traits.

\begin{tabular}{lcccc}
\hline & \multicolumn{4}{c}{ Litter size } \\
\cline { 2 - 5 } Item & 1 & 2 & 3 & 4 \\
\hline No. of records & 9258 & 8786 & 854 & 78 \\
Total milk yield, L & $311^{\mathrm{a}}$ & $329^{\mathrm{b}}$ & $331^{\mathrm{bc}}$ & $311^{\mathrm{abc}}$ \\
Calculated total milk yield, L & $296^{\mathrm{a}}$ & $312^{\mathrm{b}}$ & $318^{\mathrm{b}}$ & $296^{\mathrm{ab}}$ \\
Lactation length, d & $167^{\mathrm{a}}$ & $169^{\mathrm{b}}$ & $169^{\mathrm{abc}}$ & $169^{\mathrm{bc}}$ \\
Lambing interval, d & $280^{\mathrm{a}}$ & $283^{\mathrm{b}}$ & $284^{\mathrm{abc}}$ & $291^{\mathrm{abc}}$ \\
Maximum secretion potential, L & $2.78^{\mathrm{a}}$ & $2.92^{\mathrm{b}}$ & $2.95^{\mathrm{bc}}$ & $2.75^{\mathrm{abc}}$ \\
Peak yield, L & $2.51^{\mathrm{a}}$ & $2.64^{\mathrm{b}}$ & $2.67^{\mathrm{bc}}$ & $2.49^{\mathrm{abc}}$ \\
GM, ${ }^{\mathrm{b}}$ L/d & $68^{\mathrm{a}}$ & $71^{\mathrm{b}}$ & $70^{\mathrm{ab}}$ & $65^{\mathrm{ab}}$ \\
Persistency, ${ }^{2}$ L/d & $11.4^{\mathrm{a}}$ & $12.0^{\mathrm{b}}$ & $12.1^{\mathrm{b}}$ & $11.2^{\mathrm{ab}}$ \\
\hline
\end{tabular}

a,b,c Means within row having different superscript letters differ $(P<0.05)$.

${ }^{1} \mathrm{GM}=$ Increase in milk yield midway between lactation start and peak.

${ }^{2}$ Persistency $=$ decrease in milk yield halfway between lactation peak and end.

the older lactations, there was a constant persistency of approximately $12 \mathrm{~g} / \mathrm{d}$.

\section{Age at First Lambing and Milk Production}

On average, Assaf ewes lambed for the first time at $14.6 \pm 2.4$ mo of age, ranging from 10.2 to $28.4 \mathrm{mo}$, with only a few cases $>22$ mo. The results of analyzing the first lactation data using the modified model 2 are summarized in Table 5. Age at first lambing affected $(P<$ 0.05 ) the majority of traits, except for lactation length, lambing interval, relative death rate of cells in late lactation, and persistency. The regression coefficients shown in Table 5 indicated increased milk yield $(P<$ $0.001)$ and litter size $(P<0.05)$, as ewes were mated at older ages for the first time. For each month, increase
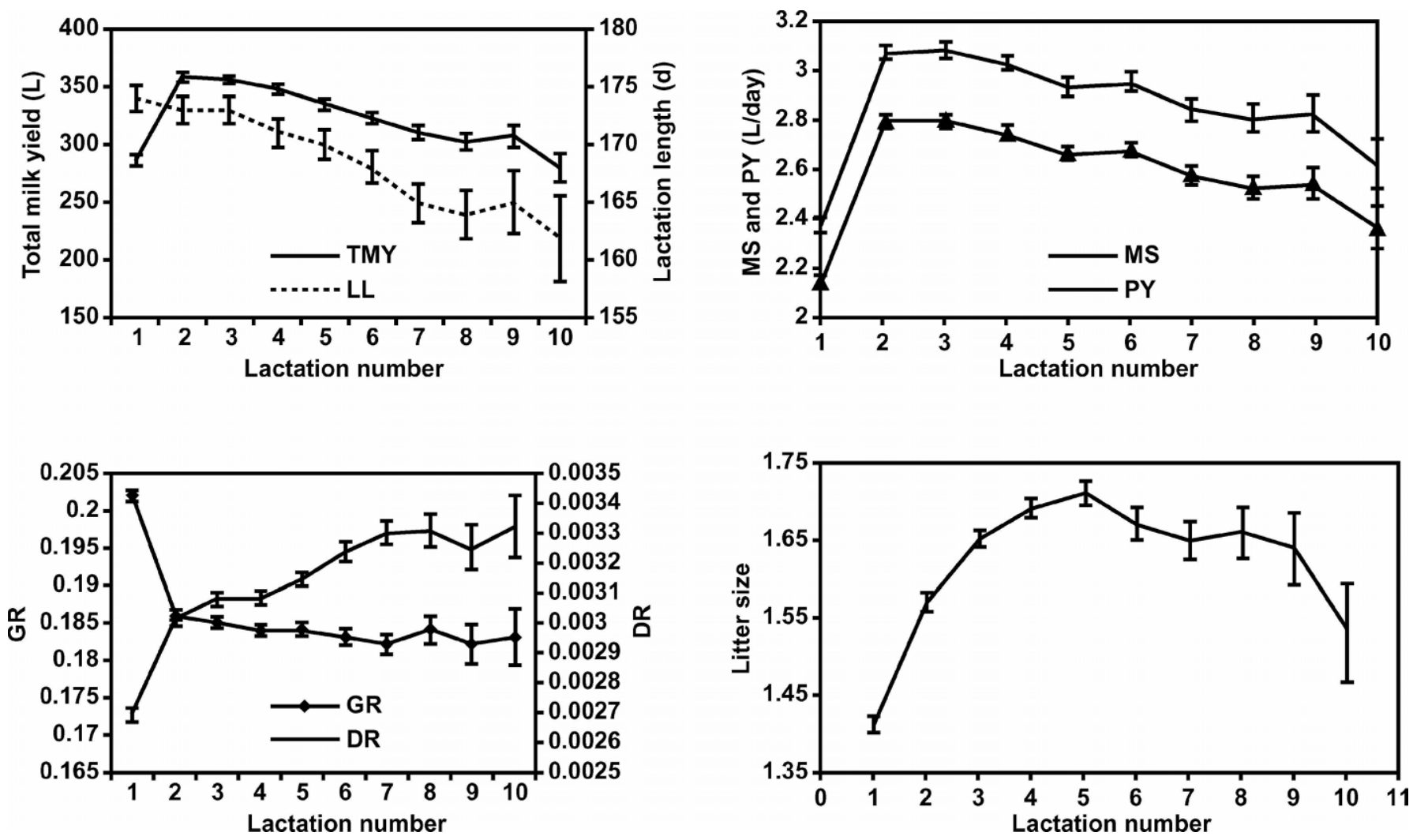

Figure 3. Least square means ( \pm SE) to illustrate the effect of lactation number on total milk yield (TMY), lactation length (LL), maximum secretion potential (MS), peak yield (PY), relative growth rate in cell numbers (GR), relative death rate in cell numbers (DR), and litter size. 
Table 5. Summary of ANOVA investigating the effect of age at first lambing on 11 traits from 4597 ewes in their first lactation.

\begin{tabular}{|c|c|c|c|c|c|c|c|}
\hline Trait & Mean & $\mathrm{LS}^{3}$ & FMY $^{4}$ & $\mathrm{MC}^{5}$ & $\mathrm{MC}^{2}$ & AFL coeff ${ }^{6}$ & $\begin{array}{l}\text { AFL coeff } \\
\text { 2nd lactation }\end{array}$ \\
\hline Litter size & 1.39 & - & **** & NS & NS & $* 0.009$ & \\
\hline Total milk yield, L & 289 & * & *** & **** & $* * *$ & ***3.7 & $*-1.82$ \\
\hline Lactation length, $\mathrm{d}$ & 175 & NS & **** & **** & $* * *$ & NS & \\
\hline Lambing interval, $\mathrm{d}$ & 274 & NS & $* * *$ & - & - & NS & \\
\hline Day of peak yield & 28.2 & NS & $* * *$ & NS & NS & $* *-0.221$ & \\
\hline Peak yield, L & 2.17 & ** & $* * *$ & * & NS & $* * * 0.0219$ & \\
\hline Calculated total milk yield, L & 273 & $*$ & $* * *$ & **** & $* * *$ & $* * * 3.81$ & $*-1.89$ \\
\hline Maximum secretion potential, L & 2.41 & ** & $* * *$ & NS & NS & $* * * 0.0213$ & \\
\hline Relative growth rate in cell numbers & 0.028 & NS & $* * *$ & NS & NS & $* * *-0.00102$ & \\
\hline Relative death rate in cell numbers & 0.0127 & NS & $* * *$ & **** & **** & NS & \\
\hline $\mathrm{GM},{ }^{1} \mathrm{~g} / \mathrm{d}$ & 68 & NS & $* * *$ & NS & NS & $* 0.833$ & \\
\hline Persistency, ${ }^{2} \mathrm{~g} / \mathrm{d}$ & 8.34 & * & **** & $* * *$ & * & NS & \\
\hline \multicolumn{8}{|l|}{$* P<0.05$} \\
\hline \multicolumn{8}{|l|}{$* * P<0.01$} \\
\hline \multicolumn{8}{|l|}{$* * * P<0.001$} \\
\hline \multicolumn{8}{|c|}{${ }^{1} \mathrm{GM}=$ Increase in milk yield midway between lactation start and peak. } \\
\hline \multicolumn{8}{|c|}{${ }^{2}$ Persistency $=$ decrease in milk yield halfway between lactation peak and end. } \\
\hline \multicolumn{8}{|c|}{${ }^{3} \mathrm{LS}=$ Litter size. } \\
\hline \multicolumn{8}{|c|}{${ }^{4} \mathrm{FMY}=$ Flock, month, and year of record. } \\
\hline \multicolumn{8}{|c|}{${ }^{5} \mathrm{MC}=$ Month in lactation when conception occurred. } \\
\hline
\end{tabular}

in age at first lambing total milk yield increased by 3.7 $\mathrm{L}$ and litter size by 0.009 lambs; thus, mating ewe lambs 1 yr later would, on average, result in more milk (44.4 L) and 0.108 more lambs born per ewe during first lactation. This greater milk yield was achieved because of a greater milk secretion potential of the mammary gland. Table 5 also shows that ewes lambing at older ages to begin their first lactation also had reduced milk yields during their second lactation $(P<0.05)$.

The effect of litter size on milk production was evident in first-lambing ewes through its association with peak yield and persistency (Table 5). Month of lactation in which conception occurred also was associated with milk yield, lactation length, and persistency $(P<0.001)$ in first lactation.

\section{Analysis of Daily Milk Yield Records}

A total of 148,765 test-day milk yields were available for analysis from 27,052 lactations of 9660 ewes. The results of analyzing these records using model 3, with both month of record and the environmental variables, are summarized in Table 6 . Mean daily milk yield was $1.73 \mathrm{~L}$. The main effects found to influence total milk yield also were found to affect $(P<0.05)$ daily milk yield, except in this analysis, month and year related to the date of the test day rather than the date of lambing used in Table 2. Least square means of daily milk yield for week of lactation are shown in Figure 4 and represent a "typical" Assaf lactation curve under inten- sive Israeli conditions. This is compared with the typical Awassi lactation curve reported by Gootwine and Pollott (2000). This overall curve had a peak yield of 2.37 $\mathrm{L} / \mathrm{d}$ at d 28 of lactation. Calculated total milk yield was $327 \mathrm{~L}$ at the average lactation length, with a persistency showing a decline of $10 \mathrm{~g} / \mathrm{d}$ midway between the peak and end of lactation. Cell numbers had a relative growth rate of 0.064 . Comparative values from the overall Awassi curve (Pollott and Gootwine, 2000) were a peak yield of $3.34 \mathrm{~L}$ on d 27 of lactation, with a total calculated milk yield of $543 \mathrm{~L}$ and a persistency decline of $15.3 \mathrm{~g} / \mathrm{d}$. Relative cell number increase in early lactation was 0.114 in the Awassi.

Distribution of milk production from Assaf ewes throughout the year followed the distribution of lambings, peaking from April to June and reaching a nadir during October. Average daily milk production was greatest during May at $2.00 \mathrm{~L}$ and decreased to $1.48 \mathrm{~L}$ during September, with an overall mean of $1.73 \mathrm{~L}$ and a standard deviation of $0.93 \mathrm{~L}$. Least square means for daily milk yield varied during the year, with a peak in May and a nadir in December (Figure 5).

\section{Seasonal Changes in Milk Yield}

Effect of replacing the month of test-day record by 5 environmental variables is shown in Table 6 (model 4). Heat load, day length, day-length change, and day length during the last month of pregnancy all affected $(P<0.001)$ daily milk yield. When the interaction of 
Table 6. ANOVA table summary accounting for effects of environmental variables on daily milk yield.

\begin{tabular}{|c|c|c|c|c|c|}
\hline Source & $\mathrm{df}$ & Model 3 MS & $P$ & Model 4 MS & $P$ \\
\hline Ewe & 9662 & 5.71 & $* * *$ & 5.88 & $* * *$ \\
\hline Farm & 4 & 264 & **** & 272 & $* * *$ \\
\hline Lambing number (LNO) & 9 & 552 & $* * *$ & 646 & $* * *$ \\
\hline Litter size (LS) & 3 & 31.6 & $* * *$ & 89.5 & $* * *$ \\
\hline Month of conception & 24 & 3.70 & $* * *$ & 5.84 & $* * *$ \\
\hline Week of lactation (week) & 46 & 130 & $* * *$ & 118 & $* * *$ \\
\hline Week from conception & 77 & 10.9 & $* * *$ & 9.39 & $* * *$ \\
\hline Month & 11 & 31.6 & $* * *$ & & \\
\hline Year & 9 & 8.48 & $* * *$ & 42.5 & $* * *$ \\
\hline Farm $\times$ LNO & 36 & 10.9 & $* * *$ & 13.7 & $* * *$ \\
\hline Farm $\times$ LS & 12 & 3.99 & **** & 5.03 & $* * *$ \\
\hline Farm $\times$ week & 159 & 7.83 & $* * *$ & 6.48 & $* * *$ \\
\hline Farm $\times$ month & 43 & 3.57 & $* * *$ & & \\
\hline Farm $\times$ year & 28 & 8.91 & *** & 29.9 & $* * *$ \\
\hline Farm $\times$ year $\times$ month & 303 & 11.1 & $* * *$ & & \\
\hline Day length (DL) & 1 & & & 2177 & $* * *$ \\
\hline Day length change (DC) & 1 & & & 35.9 & $* * *$ \\
\hline DL pre-lambing (DLP) & 1 & & & 15.1 & $* * *$ \\
\hline DC pre-lambing (DCP) & 1 & & & 0.64 & NS \\
\hline Heat load (HL) & 1 & & & 19.9 & **** \\
\hline Farm $\times$ DL & 5 & & & 69.4 & $* * *$ \\
\hline Farm $\times$ DC & 5 & & & 29.8 & $* * *$ \\
\hline Farm $\times$ DLP & 5 & & & 25.3 & $* * *$ \\
\hline Farm $\times$ DCP & 5 & & & 13.2 & $* * *$ \\
\hline Farm $\times \mathrm{HL}$ & 5 & & & 40.1 & $* * *$ \\
\hline $\mathrm{R}^{2}$ & 0.569 & & & 0.576 & \\
\hline Residual mean square & 0.402 & & & 0.394 & \\
\hline
\end{tabular}

$* * * P<0.001$.

farm and the 5 variables was fitted to daily milk yield, all variables were found to be significant $(P<0.001)$. Day length had the greatest effect on daily milk yield and change in day length before lambing, the least effect. Fitting model 4 to the data resulted in a similar fit to model 3. Linear regression coefficients for each environmental variable were: day length $=0.121 \pm 0.002$ $\mathrm{h}$, day length change $=0.0009 \pm 0.003 \mathrm{~min}, \mathrm{HL} / 2=$ $-0.0017 \pm 0.0002$ index units, day length during pregnancy $=-0.0069 \pm 0.002 \mathrm{~h}$, and day length change during pregnancy $=-0.0002 \pm 0.0002 \mathrm{~min}$.

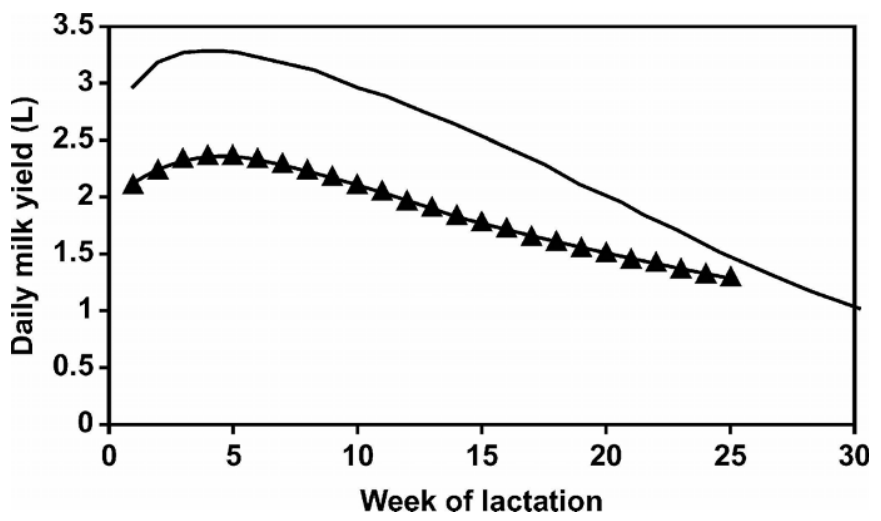

Figure 4. A comparison of the "typical" Assaf (- - -) and Awassi (-) lactation curves.
Using these regression coefficients, the effects of day length, day length change, and heat load on daily milk production on the 15th day of each month of the year was calculated (Table 7). It was estimated, based on the combined effects of the 3 seasonal factors, that daily milk yields during mid-June were $0.235 \mathrm{~L}$ above average, whereas during mid-December, daily milk yields were reduced by $0.205 \mathrm{~L}$, mainly due to shorter day length.

Unlike the lactational day-length effect, day length before lambing had an inverse effect on milk production

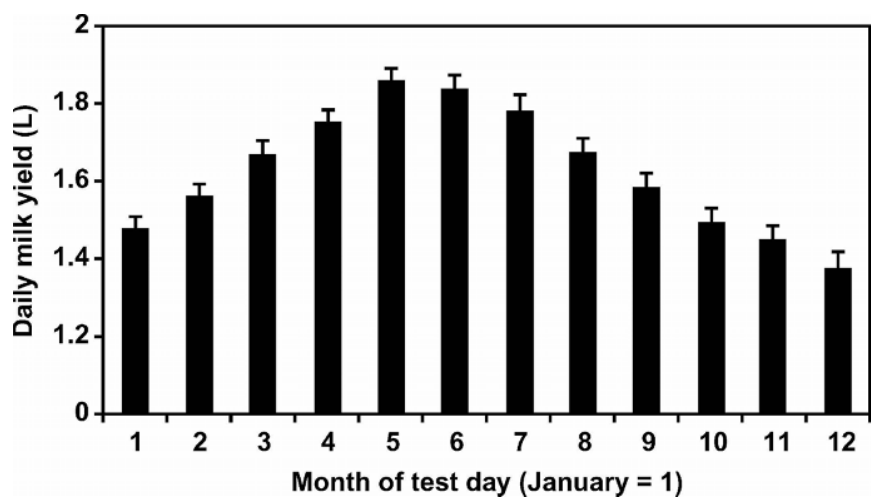

Figure 5. Effect of month of test on daily milk production (least square means $\pm \mathrm{SE})$. 
Table 7. Contribution of the 4 environmental variables to test-day milk yields throughout the year expressed as deviations from a mean of zero.

\begin{tabular}{llllll}
\hline Month & $\begin{array}{l}\text { Day length } \\
\text { (DL) }\end{array}$ & $\begin{array}{l}\text { Day length } \\
\text { change (DC) }\end{array}$ & $\begin{array}{l}\text { Heat load } \\
\text { (HL) }\end{array}$ & $\begin{array}{l}\text { Combined DL } \\
\text { + DC + HL effects }\end{array}$ & $\begin{array}{l}\text { DL } \\
\text { pre-lambing }\end{array}$ \\
\hline 1 & $-0.227^{1}$ & 0.012 & 0.024 & -0.191 & 0.014 \\
2 & -0.171 & 0.034 & 0.024 & -0.113 & 0.010 \\
3 & -0.077 & 0.039 & 0.024 & -0.014 & 0.005 \\
4 & 0.033 & 0.043 & 0.024 & 0.100 & -0.002 \\
5 & 0.139 & 0.034 & 0.017 & 0.190 & -0.009 \\
6 & 0.214 & 0.015 & 0.006 & 0.235 & -0.013 \\
7 & 0.229 & -0.012 & -0.015 & 0.202 & -0.014 \\
8 & 0.176 & -0.034 & -0.044 & 0.098 & -0.005 \\
9 & 0.077 & -0.042 & -0.044 & -0.009 & 0.002 \\
10 & -0.035 & -0.042 & -0.034 & -0.111 & 0.009 \\
11 & -0.142 & -0.034 & -0.005 & -0.181 & 0.013 \\
12 & -0.216 & -0.013 & 0.024 & -0.205 & \\
\hline
\end{tabular}

${ }^{1}$ For DL, DC, and HL, values represent test days on the 15 th of the month. For DLP and DCP, values represent lambings on the first of the month.

(Table 7). Ewes that experienced short or long days before lambing had more or less daily milk yields throughout the lactation, respectively. Although significant $(P<0.001)$, this prepartum seasonal effect on milk production was relatively small. Thus, ewes lambing in January produced $0.014 \mathrm{~L}$ more milk daily throughout the lactation (Table 7). This accumulated, during the average lactation of $173 \mathrm{~d}$ (Table 1), to an addition of only $2.4 \mathrm{~L}$ of milk to the total yield of 334 L. As shown in Figure 2, seasonal factors may increase or decrease total milk production by $\pm 4 \%$ (approximately $15 \mathrm{~L}$ ). The environmental variable effects on milk production accounted for most of the seasonal effects.

\section{Relationship Between Conception and Milk Production}

Time postpartum when conception occurred was related to all traits $(P<0.01)$, except the maximum secretion potential of the lactation (Table 2 ). The quadratic term in the model $\left(M C^{2}\right)$ was significant $(P<0.05)$ for litter size, total milk yield, CTMY, lactation length, relative death rate of cells in late lactation, peak yield, and persistency, indicating that the relationship between time of conception and month of lactation when conception occurred was curvilinear for these traits. Less total milk yield and shorter lactations were associated with early conception (Figure 6). Early conception was associated with lactations having less persistency, smaller peak yields, and fewer lambs (Figure 7).

Conception had a short-term effect on milk production (Figure 8). A sharp increase in milk production occurred approximately 1 to $2 \mathrm{wk}$ after conception, followed by a return to preconception levels by $4 \mathrm{wk}$ and then a drop in milk yield as pregnancy progressed.
The relationship between peak yield and month after birth when conception occurred was investigated. Mean $M C$ rose with increasing peak yield, but this rise was small: 4.3 mo at a peak yield of $1 \mathrm{~L}$ to $4.9 \mathrm{mo}$ at a peak yield of $4 \mathrm{~L}$. Thus, there was just an 18-d difference between ewes having peak yields \pm 4 SD of the mean.

\section{DISCUSSION}

Intensive management in sheep breeding, in which environmental conditions are optimized, is aimed at fully exploiting the ewe's reproductive and productive potential. In the present study, the lamb and milk production of Assaf ewes managed under intensive conditions were investigated. Assaf ewes, on average, lambed for the first time at 14.6 mo of age and continued to lamb every $9 \mathrm{mo}$, with average prolificacy of 1.57 lambs/ lambing. Ewes produced on average $334 \mathrm{~L}$ of milk/lactation, with average lactation length of $173 \mathrm{~d}$. On an

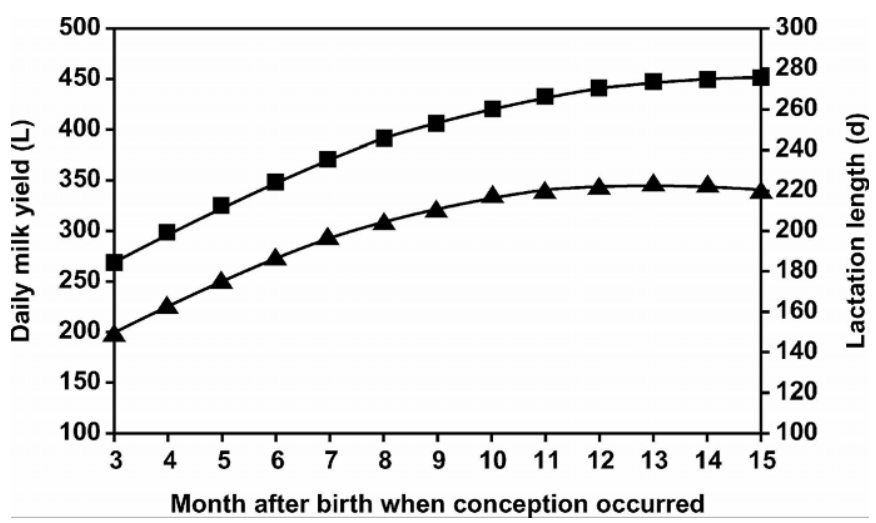

Figure 6. Milk yield (TMY; - - -) and lactation length (LL; - $\mathbf{-}-)$ related to the month after birth when conception occurred. 


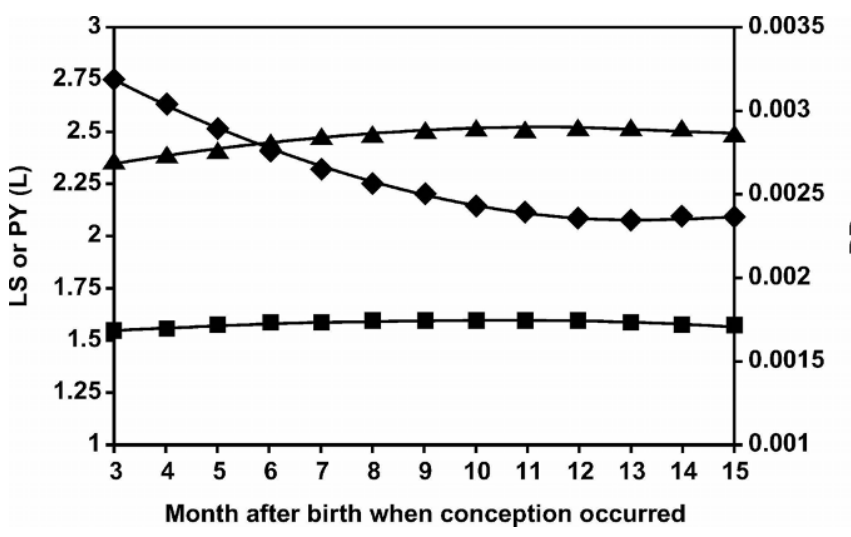

Figure 7. Peak yield (PY; - $-\mathbf{\Delta}-)$, litter size (LS; - - - ), and relative death rate in cell numbers (DR; - -) in relation to the month after birth when conception occurred.

annual basis, Assaf ewes produced 2.1 lambs and 448 $\mathrm{L}$ of milk. In comparison, improved Awassi ewes, kept under similar intensive management conditions (Gootwine and Pollott, 2000), annually produced fewer lambs (1.4) but more milk (560 L; Table 1).

Lamb and milk production contribute almost equally to the gross income of the dairy flocks in Israel. Under such market conditions, the Assaf with its relatively greater lamb production has an economic advantage over the Improved Awassi, even though its milk production is lower. This is why, since its development in the 1960 s, the Assaf has gradually replaced the Improved Awassi in most of the dairy flocks in Israel.

\section{Lamb Production}

Age of ewe was found to affect prolificacy in these Assaf ewes. Litter size rose gradually as age at first lambing increased and then peaked at the fifth lambing, with 1.71 lambs born/ewe lambing (Figure 3). Unlike

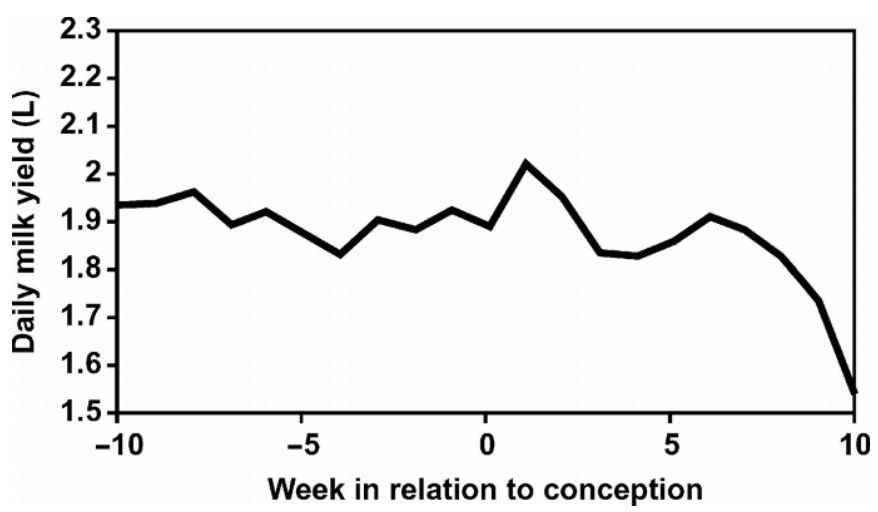

Figure 8. Daily milk yield in relation to time of conception. sheep production systems in which ewes are bred naturally during a single breeding season in the autumn, reproductive management in Assaf flocks involves several mating or insemination seasons per year, in which estrus is hormonally synchronized before mating. Ewes that fail to conceive are hormonally treated and bred again at the next mating period. As a result, lambings are unevenly distributed throughout the year. Relatively fewer lambs were born during July and August, reflecting fewer matings or inseminations during February and March. Such matings are considered "out of season" and are characterized by relatively low conception rates.

Mean litter size varied throughout the year (Figure 2 ), with peaks in February resulting from matings in September, and in September resulting from matings in April. As indicated, estrus in these ewes was synchronized by hormonal treatment. Further study is needed to explain the seasonal effect on ovulation rate and embryo survival obtained following these treatments.

As lamb production is an important source of income in Assaf flocks, selection for higher prolificacy could be considered as a way to improve production. However, the low repeatability value obtained in the present study for litter size (0.05) indicated a slow response to such selection. Introgression of the $\mathrm{Fec}_{\mathrm{B}}$ (Booroola) major gene (Gootwine et al., 2001) to the Assaf was found to be a useful alternative way to improve its lamb production.

\section{Milk Production}

Analyzing Assaf lactational traits by applying a biological model (Pollott, 2000) and comparing the results with those of the Improved Awassi provide insight into the milking ability of the Assaf. Compared with the Improved Awassi (Table 1, Figure 4), the Assaf had shorter lactations ( 173 vs. $214 \mathrm{~d}$, respectively), and they produced less milk throughout lactation (334 vs. 506 L). Whether differences are genetic or environmental in origin cannot be determined from this study because both breeds were not managed under similar conditions. Nevertheless, these results indicate that the "typical" Assaf lactation curve differs from that of the Improved Awassi in traits related mainly to the early stage of the lactation: lower maximum secretion potential $(2.89 \mathrm{v} 3.90 \mathrm{~L})$ and smaller peak yields $(2.61 \mathrm{v} 3.44 \mathrm{~L})$. From the overall curves shown in Figure 4, both breeds peaked during the fourth week of lactation, and the Awassi had both a faster relative increase in cell numbers during early lactation and a faster decrease during late lactation. 


\section{Change in Lactation Parameters with Age at First Lambing and Lactation Number}

First lambing occurred in the Assaf between 10 and 28 mo of age. Ewe lambs that were older at first lambing produced more milk than younger ewes. These results agree with results reported for the Lacaune (Barillet et al., 1992), Latxa (Gabina et al., 1993), and Awassi (Gootwine and Pollott, 2000) breeds. Delaying age at first lambing by 1 mo increased total milk yield in the first lactation by 3.7 L (Table 5), whereas loss of potential milk production during that month was estimated to be of $49.5 \mathrm{~L}$. (Average daily milk production during first lactation was $1.65 \mathrm{~L}$.) Thus, under intensive management, breeding ewe lambs at an early age is economically justified. As with Awassi sheep (Gootwine and Pollott, 2000), breeding ewe lambs at an early age had no or little effect on milk production in later lactations.

Ewes in their first lactation produced less milk, whereas those in their second and third lactations produced the most milk (Figure 3). Decline in milk yield was associated with shorter lactation lengths, less maximum secretion potential, less relative growth rate in cell numbers, and higher relative death rate of cells during late lactation.

Increased milk-producing ability, either as age progressed in the first lactation or between first and second lactations, was associated with greater peak yields and greater maximum secretion potential, indicating that more secretory cells developed in ewes bred at older ages. In the same way, the relative proliferation rate of secretory cell numbers during early lactation declined in both situations, suggesting that greater milk production throughout lactation was associated with udders being in a more advanced stage of development before parturition. Interestingly, although relative decline in mammary cell numbers during later lactation increased between first and second lactations (Figure 3 ), it did not change, as milk production during the first lactation increased with age at first lambing (Table 5).

\section{Litter Size and Milk Production}

In the present study, twin- and triplet-bearing ewes produced approximately 6\% more milk than those carrying only 1 lamb (Table 4). A similar effect of litter size on milk production was reported for Awassi sheep (Gootwine and Pollott, 2000). This increase in milk production was mainly due to an increase in early lactation parameters such as MS, peak yield, and the increase in milk yield midway between the start and peak of lactation, suggesting a differential effect of fetal numbers on mammary development during pregnancy. Relationships between the number of fetuses carried and mammary growth and milk yield have been demon- strated in a number of polytocous species (Knight and Sorenson, 2001) and is thought to be mediated through fetoplacental production of placental lactogen (Schoknecht et al., 1991). Although concentration of placental lactogen in blood circulation during pregnancy was almost twice as great in twin-bearing ewes than in singlebearing ewes (Gootwine, 2004), milk production only increased by $6 \%$.

\section{Conception and Milk Production}

Greater milk production through lactation was associated with a longer postpartum interval (Table 2, Figures 6 and 7), confirming results obtained previously with both Assaf and Awassi sheep managed under a variety of management conditions (Eyal et al., 1978; Kassem et al., 1989; Gootwine and Pollott, 2000). Elevated milk yields at the beginning of lactation may delay conception, due to negative energy balance, as reported for dairy cattle (Butler, 2000; Pryce et al., 2004). Although a positive association between peak yield, which usually occurs prior to conception, and MC was observed in this study, the actual difference in conception time during lactation between relatively low-yielding ewes (peak yield $<2 \mathrm{~L}$ ) and high-yielding ewes (peak yield $>4 \mathrm{~L}$ ) was only a few days. Thus, association between total milk yield and $\mathrm{MC}$ in the Assaf was related more to the effect of conception on subsequent milk production during lactation, in which relatively early conception was associated with early drying off before next lambing.

By aligning daily milk records to the day of conception, a temporary rise in milk production following conception was observed (Figure 8), peaking at approximately 1 to 2 wk after conception. Similar results were reported previously for Awassi sheep (Gootwine and Pollott, 2000). This temporary rise in milk production seems to be different in timing and magnitude from the variation in milk production over the estrous period (Schofield et al., 1991). The observed elevation in milk production may be related to the establishment of the corpus luteum in pregnant ewes. Indeed, evidence that the presence of the corpus luteum increases milk production has been documented in sheep, and the hypothesis that this effect is mediated through oxytocin secretion has been promoted (McKusick et al., 2002). However, the temporary status of this elevation of milk production warrants further study.

\section{Seasonality Effects on Milk Production}

Seasonality affects milk production of Assaf sheep (Figure 5), and change in day length explained much of this effect (Tables 6 and 7). A similar photoperiodic 
effect on milk production was reported for Awassi sheep (Gootwine and Pollott, 2000). Several studies have shown that long days also stimulate milk yield in dairy cattle (Aharoni et al., 1999, 2000; Dahl et al., 2000). Although a physiological explanation for the possible photoperiod effect on milk production in sheep is not yet clear, using artificial lightning to extend day length during winter is suggested to improve milk production of ewes. As indicated by Gootwine and Pollott (2000), photoperiodic effects on breeding activity and on milk production in sheep act in an antagonistic way. Thus, economic outcomes on both lamb and milk production must be considered before applying means to manipulate seasonality in Assaf dairy ewes.

Seasonality effects commonly found in other sheepproduction systems include the effect of variation in nutrition from grazed material. This effect is likely to be minimal in these flocks due to the lack of grazing and the effect of feeding ewes to match their milk yield.

It is worth noting that ewes lambing in May and December had very similar total milk yield (Figure 2), but it occurred by different mechanisms. May-lambing ewes had greater yields because of exposure to longer day length during summer (Table 7). But this was reduced by both heat load and day-length change during that period. In contrast, December-lambing ewes had a relatively low contribution from day length but virtually no negative effect of heat load and a positive effect of day-length change.

Day length before lambing was found to have a significant effect on milk production (Table 6) in which prepartum short days had a positive effect on milk production in the following lactation (Table 7). A similar positive effect of short days on milk production was found in dairy cattle (Aharoni et al., 2000). In addition, dairy cattle exposed to short day length during the dry period had increased milk production in the subsequent lactation (Miller et al., 2000).

It is not yet clear how the short days during the prepartum period positively affects subsequent milk production. One possibility is that photoperiod directly affects expression and activity of hormones like progesterone, prolactin, and placental lactogen that regulate mammary development during pregnancy (Neville et al., 2002). Alternatively, exposure to short days may modify the responsiveness of ewes to day length stimuli to which they are exposed after parturition.

The prepartum short-day photoperiod effect estimated in the present study was relatively small. However, a stronger short-day effect that can be induced for an extended period of time may result in a stronger stimulus on milk production. Such an effect can be induced artificially using commercial melatonin implants to mimic a short-day environment in a similar manner to the way they are applied to induce out-of-season breeding activity in sheep and goats (Chemineau et al., 1992).

\section{CONCLUSIONS}

Intensive management is targeted to exploit the full biological potential of sheep. In terms of output per year, Assaf sheep bearing 2.1 lambs and producing 448 $\mathrm{L}$ of milk have a high level of production. Whether the full production potential of the breed has been achieved is not known. Being a dual-purpose breed, managed for both lamb and milk production, optimizing production in the Assaf in one direction may be counter-productive in the other direction. Thus, high milk production is associated with a delay in conception, and the shortday photoperiod effect that enhances breeding activity also may negatively affect milk production.

Using a biological model (Pollott 2000), it was possible to compare typical lactation curves of the Improved Awassi and the Assaf breeds, and to describe their differences in terms of early and late lactation traits. This information can be used to better define goals for selection for more milk production in the Assaf. Recent introduction of electronic identification and computerized daily milk recording in the Assaf dairy flocks provides an opportunity to calculate accurately those traits for each lactation and use the results for breeding or managerial decisions.

\section{ACKNOWLEDGMENTS}

We thank the devoted teams who manage these Assaf flocks for their collaboration and help, and the Israel Meteorological Service for providing meteorological information.

\section{REFERENCES}

Aharoni, Y., A. Brosh, and E. Ezra. 1999. Effect of heat load and photoperiod on milk yield and composition in three dairy herds in Israel. Anim. Sci. 69:37-47.

Aharoni, Y., A. Brosh, and E. Ezra. 2000. Prepartum photoperiod effect on milk yield and composition in dairy cows. J. Dairy Sci. 83:2779-2781.

Barillet, F., D. Boichard, A. Barbat, J. M. Astruc, and B. Bonaiti. 1992. Use of an animal model for genetic evaluation of the Lacaune dairy sheep. Livest. Prod. Sci. 31:287-299.

Butler, W. R. 2000. Nutritional interactions with reproductive performance in dairy cattle. Anim. Reprod. Sci. 60-61:449-457.

Chemineau, P. B., J. A. Malpaux, Y. Delgadillo, J. P. Guerin, J. P. Ravault, J. Thimonier, and J. Pelletier. 1992. Control of sheep and goats reproduction: Use of light and melatonin. Anim. Reprod. Sci. 30:157-184.

Dahl, G. E., B. A. Buchanan, and H. A. Tucker. 2000. Photoperiodic effects on dairy cattle: A review. J. Dairy Sci. 83:885-893.

Epstein, H. 1985. The Awassi sheep with special reference to the Improved dairy type. Anim. Prod. Hlth. no. 57. FAO, Rome, Italy. 
Eyal, E., A. Lawi, Y. Folman, and M. Morag. 1978. Lamb and milk production of a flock of dairy ewes under an accelerated breeding regime. J. Agric. Sci. Camb. 91:69-79.

Gabina, D., F. Arrese, J. Arranz, and I. Beltran de Heredia. 1993. Average milk yields and environmental effects on Latxa sheep. J. Dairy Sci. 76:1191-1198.

Gilmour, A. R., B. J. Gogel, B. R. Cullis, S. J. Welham, and R. Thompson. 2002. ASReml User Guide, Release 1.0. VSN Int. Ltd., Hemel Hempstead, UK.

Goot, H. 1974. Milk yield and lactation length of single- and twinrearing Assaf dairy sheep. Israel J. Agric. Res. 23:155-158.

Gootwine, E. 2004. Placental hormones and feto-placental development in ruminants. Anim. Reprod. Sci. 82-83:551-566.

Gootwine, E., and H. Goot. 1996. Lamb and milk production of Awassi and East-Friesian sheep and their crosses under Mediterranean environment. Small Rumin. Res. 20:255-260.

Gootwine, E., H. Leibovich, G. Waisel, A. Zenou, and I. Spormas. 1994. "Ewe and Me"-on-farm software for dairy and mutton sheep and goats flocks. Pages 67-68 in 5th World Congr. Genet. Appl. Livest. Prod. University of Guelph, Ontario, Canada.

Gootwine, E., and G. E. Pollott. 2000. Factors affecting milk production in Improved Awassi dairy ewes. Anim. Sci. 71:607-615.

Gootwine, E., and G. E. Pollott. 2002. Factors affecting the milk production of Assaf dairy sheep in Israel. 7th World Congr. Genet. Appl. Livest. Prod., Montpellier, France. CD-ROM communication no. 01-48.

Gootwine, E., A. Zenu, A. Bor, S. Yossafi, A. Rosov, and G. E. Pollott. 2001. Genetic and economic analysis of introgressing the B allele of the $\mathrm{Fec}_{\mathrm{B}}$ (Booroola) gene into Awassi and Assaf dairy breeds. Livest. Prod. Sci. 71:49-58.

Kassem, R., J. B. Owen, and I. Fedel. 1989. Rebreeding activity in milking Awassi ewes under semi-arid conditions. Anim. Prod. 49:89-93.

Knight, C. H., and A. Sorenson. 2001. Windows in early mammary development: Critical or not? Reprod. 122:337-345.
McKusick, B. C., M. C. Wiltbank, R. Sartori, P. G. Marnet, and D. L. Thomas. 2002. Effect of presence or absence of corpora lutea on milk production in East Friesian dairy ewes. J. Dairy Sci. 85:790-796.

Miller, A. R. E., R. A. Erdman, L. W. Douglass, and G. E. Dahl. 2000. Effects of photoperiodic manipulation during the dry period of dairy cows. J. Dairy Sci. 83:962-967.

Neville, M. C., T. B. McFadden, and I. Forsyth. 2002. Hormonal regulation of mammary differentiation and milk secretion. J. Mammary Gland Biol. Neoplasia 7:49-66.

Pollott, G. E. 2000. A biological approach to lactation curve analysis. J. Dairy Sci. 83:2448-2458.

Pollott, G. E., and E. Gootwine. 2000. Appropriate mathematical models for describing the lactation of dairy sheep. Anim. Sci. 71:197-207.

Pollott, G. E., and E. Gootwine. 2001. A genetic analysis of complete lactation milk production in Improved Awassi Sheep. Livest. Prod. Sci. 71:37-47.

Pryce, J. E., M. D. Royal, P. C. Garnsworthy, and I. L. Mao. 2004. Fertility in the high-producing dairy cow. Livest. Prod. Sci. 86:125-135.

Schofield, S. A., C. J. C. Phillips, and A. R. Owens. 1991. Variation in the milk production, activity rate and impedance of cervical mucus over the oestrus period of dairy cows. Anim. Reprod. Sci. 24:231-248.

Schoknecht, P. A., S. N. Nobrega, J. A. Petterson, R. A. Ehrhardt, R. Slepetis, and A. W. Bell. 1991. Relations between maternal and fetal plasma concentrations of placental lactogen and placental and fetal weights in well-fed ewes. J. Anim. Sci. 69:1059-1063.

SAS User's Guide, Version 6, 4th ed., Vol. 2, GLM-VARCOMP. 1989 SAS Institute, Inc., Cary, NC.

Ugarte, E., R. Ruiz, and I. Beltran de Heredia. 2000. Impact and influence of foreign breeds on Spanish breeds of dairy sheep. Livest. Prod. Sci. 71:3-10. 